DOI: http://dx.doi.org/10.18203/2320-1770.ijrcog20170959

Original Research Article

\title{
Clinical study of vesicular mole
}

\section{Harshada S. Thakur*}

Department of Obstetrics and Gynecology, Seth Gordhandas Sunderdas Medical College, King Edward Memorial Hospital, Mumbai, Maharashtra, India

Received: 16 February 2017

Revised: 25 February 2017

Accepted: 27 February 2017

*Correspondence:

Dr. Harshada S. Thakur,

E-mail: harshadatha210@gmail.com

Copyright: ( ) the author(s), publisher and licensee Medip Academy. This is an open-access article distributed under the terms of the Creative Commons Attribution Non-Commercial License, which permits unrestricted non-commercial use, distribution, and reproduction in any medium, provided the original work is properly cited.

\section{ABSTRACT}

Background: Vesicular mole is an abnormal condition where there is partly degeneration and partly hyperplastic changes in the young chorionic villi. The purpose of this study is clinical presentation of molar pregnancy, serum $\beta$ hCG regression curve and further management.

Methods: This was a prospective study undertaken in the Department of Obstetrics and Gynaecology at the tertiary care center for the study period from October 2007 to May 2009 approved by ethical committee.

Results: Incidence of vascular mole was 2.5 per 1000 deliveries. $46.15 \%$ women were in the age group 20-24 years, $33.33 \%$ in the age group $25-29$ years and $20.51 \%$ were in the teenage group. $58.97 \%$ women were between gravidity 2-4.

Conclusions: There was a significant association of serum $\beta-\mathrm{hCG}>1,00,000 \mathrm{mlU} / \mathrm{ml}$ with theca lutein cysts $>6 \mathrm{~cm}$. $11.76 \%$ women with complete mole had elevated TFT while not a single woman with partial mole had elevated TFTs.

Keywords: Complete, Partial, Theca lutein cysts

\section{INTRODUCTION}

Vesicular mole is an abnormal condition where there is partly degeneration and partly hyperplastic changes in the young chorionic villi. In $400 \mathrm{BC}$, Hippocrates $1^{\text {st }}$ described hydatidiform mole as 'dropsy of uterus'. Seckle et al reported the incidence of complete hydatidiform mole as 1:100 pregnancies and state that $15 \%$ complete hydatidiform moles are likely to be transferred into malignant gestational trophoblastic neoplasia which if undiagnosed can be rapidly fatal. ${ }^{1}$ Major breakthrough in the management was brought first time by Lee when chemotherapy was introduced for the treatment of gestational trophoblastic neoplasm.

Based on thorough pathologic review, the incidence of complete and partial mole was found to be 1 per 1945 and 1 per 695 pregnancies respectively. ${ }^{2}$ Timely diagnosis and treatment has good survival rate even in presence of disseminated disease. The purpose of this series was to study clinical presentation of molar pregnancy.

\section{METHODS}

It was prospective study approved by ethics committee undertaken in the Department of Obstetrics and Gynaecology at the tertiary care center for the study period from October 2007 to May 2009.

Statistical analysis was done with statistical package for social sciences (SPSS) version 17.0 and epi info 6.0.

Inclusion criteria include all diagnosed cases of vesicular mole in tertiary care center. 
Exclusion criteria include invasive mole and choriocarcinoma.

On admission, all women had a detailed history and examination. All women were divided on the basis of socioeconomic background by Kuppuswaami classification. All women were subjected for baseline and special investigations.

\section{Baseline investigations}

- Haemoglobin estimation.

- Urine analysis.

- Blood grouping and typing.

- Liver function tests.

- Kidney function tests.

- Bleeding time.

- Clotting time.

- ECG.

\section{Special investigations}

- $\quad$ Serum $\beta$-hCG.

- Chest X-ray (P-A) view in standing position.

- Thyroid function tests.

In all women, transabdominal and transvaginal ultrasonography was done for confirmation of diagnosis. On ultrasonography, complete molar pregnancy and typical "snow storm appearance" while partial molar pregnancy showed large placenta, cystic spaces within the placenta \& gestational sac which was either empty or containing growth retarded fetus. Theca lutein cysts showed either 'soap-bubble' or 'spoke-wheel like' appearance on ultrasonography. If women were having severe anemia ( $\mathrm{Hb}<7 \mathrm{gm} \%)$; blood transfusion was given, preferably packed cell volume. Blood was kept ready for women who were not anemic.

If, TFT's were raised and woman was having symptoms and sign i.e. warm skin, palpitation, tremors and tachycardia, $\beta$-blocker like T. propranolol 10mg BD was added. Suction evacuation was the procedure of choice. It was done by using MVA (manual vacuum aspiration) syringe.

\section{RESULTS}

Incidence of vascular mole was 2.5 per 1000 deliveries. Around 18 (46.15\%) women were in the age group 20-24 years, $13(33.33 \%)$ in the age group $25-29$ years and 8 $(20.51 \%)$ were in the teenage group. $23(58.97 \%)$ women were between gravidity 2-4, $13(33.33 \%)$ women were prim gravida and around $3(7.69 \%)$ women were gravidity 5 or more. $18(46.15 \%)$ women were nulliparous, $12(30.76 \%)$ were multiparous and 9 $(23.07 \%)$ were primipara. $17(43.58 \%)$ women of vascular mole were from Class IV socioeconomic status. No case was detected in Class I. Antecedent pregnancy as full term delivery in $18(46.15 \%)$ women and as first trimester abortion in $5(12.82 \%)$.

In complete molar pregnancy, $17(50 \%)$ women had size/height of uterus larger than period of amenorrhea, 10 (29.41\%) had size/height corresponding to period of amenorrhea while $7(20.58 \%)$ had size/height of uterus less than period of amenorrhea.

Table 1: Incidence of vesicular mole.

\begin{tabular}{|ll|}
\hline $\begin{array}{l}\text { Total number of } \\
\text { deliveries }\end{array}$ & $\begin{array}{l}\text { Number of women with } \\
\text { vascular mole }\end{array}$ \\
\hline 15059 & 39 \\
\hline
\end{tabular}

Table 2: Age wise distribution of women.

\begin{tabular}{|lll|}
\hline Age in years & Number & Percentage \\
\hline $15-19$ & 8 & 20.51 \\
\hline $20-24$ & 18 & 46.15 \\
\hline $25-29$ & 13 & 33.33 \\
\hline Total & 39 & 100 \\
\hline
\end{tabular}

In partial molar pregnancy, $3(60 \%)$ women had height/size of uterus corresponding of amenorrhea and 2 (40\%) had height/size of uterus less than period of amenorrhea. In complete mole, $21(61.76 \%)$ women were having severe anaemia $(\mathrm{Hb}<7)$. While in partial mole, 3 $(60 \%)$ women were having severe anaemia. The most common blood group combination of woman and her partner was $\mathrm{O}+\mathrm{ve}$ and $\mathrm{A}+\mathrm{ve}$ respectively followed by both having blood group $\mathrm{O}+\mathrm{ve}$.

Table 3: Clinical presentation of women.

\begin{tabular}{|lllllll|}
\hline Symptoms & Complete mole & Partial mole & No. of cases & Percentage \\
\hline & Number & Percentage & Number & Percentage & & \\
\hline Amenorrhoea & 27 & 79.41 & 3 & 60 & 30 & 76.92 \\
\hline Bleeding PV & 23 & 67.64 & 2 & 40 & 25 & 64.10 \\
\hline Pain in Abdomen & 26 & 76.47 & 4 & 80 & 30 & 76.92 \\
\hline Nausea \& Vomiting & 6 & 17.64 & 3 & 60 & 9 & 23.07 \\
\hline Cough & 2 & 5.88 & 1 & 20 & 3 & 7.69 \\
\hline Passing Vesicles per vaginum & 4 & 11.76 & 0 & 0 & 4 & 10.25 \\
\hline Total & 88 & & 13 & & 101 & \\
\hline
\end{tabular}


Complete molar pregnancy constituted 34 (87.17\%) of the study group while $5(12.82 \%)$ women had partial mole. The most common symptom of presentation in women with complete mole was amenorrhea in 27 (79.41\%) women, pain in abdomen in $26(76.47 \%)$ and bleeding $\mathrm{P} / \mathrm{V}$ in $23(67.64 \%)$. The most common symptom of presentation in women with partial mole was pain in abdomen in $4(80 \%)$ women, amenorrhea in 3 $(60 \%)$ and bleeding $\mathrm{P} / \mathrm{V}$ in $2(40 \%)$.

Table 4: Gravida wise distribution of women.

\begin{tabular}{|lll|}
\hline Gravida & Number & Percentage \\
\hline G1 & 13 & 33.33 \\
\hline G2-G4 & 23 & 58.97 \\
\hline$>$ G5 & 3 & 7.69 \\
\hline Total & 39 & 100 \\
\hline
\end{tabular}

Table 5: Blood group wise distribution of women.

\begin{tabular}{|l|l|l|}
\hline $\begin{array}{l}\text { Woman's blood } \\
\text { group }\end{array}$ & $\begin{array}{l}\text { Partner's blood } \\
\text { group }\end{array}$ & $\begin{array}{l}\text { Number } \\
\text { of cases }\end{array}$ \\
\hline O +ve & A +ve & 9 \\
\hline O +ve & O +ve & 5 \\
\hline $\mathrm{B}+\mathrm{ve}$ & $\mathrm{O}+\mathrm{ve}$ & 4 \\
\hline $\mathrm{A}+\mathrm{ve}$ & $\mathrm{O}+\mathrm{ve}$ & 4 \\
\hline $\mathrm{B}+\mathrm{ve}$ & $\mathrm{AB}+\mathrm{ve}$ & 3 \\
\hline $\mathrm{B}+\mathrm{ve}$ & $\mathrm{A}+\mathrm{ve}$ & 3 \\
\hline $\mathrm{O}+\mathrm{ve}$ & $\mathrm{AB}+\mathrm{ve}$ & 3 \\
\hline $\mathrm{A}+\mathrm{ve}$ & $\mathrm{B}+\mathrm{ve}$ & 3 \\
\hline $\mathrm{B}+\mathrm{ve}$ & $\mathrm{B}+\mathrm{ve}$ & 2 \\
\hline $\mathrm{A}+\mathrm{ve}$ & $\mathrm{A}-\mathrm{ve}$ & 1 \\
\hline $\mathrm{A}+\mathrm{ve}$ & $\mathrm{A}+\mathrm{ve}$ & 1 \\
\hline O $+\mathrm{ve}$ & $\mathrm{B}+\mathrm{ve}$ & 1 \\
\hline Total & & 39 \\
\hline
\end{tabular}

\section{DISCUSSION}

Gestational trophoblastic disease (GTD) includes a tumors and tumor like conditions that originate from the fetal chorion (hydatidiform mole, invasive mole, choriocarcinoma, placental site trophoblastic tumor). Vesicular mole is principally a disease of chorion. Death of the ovum or failure of the embryo to grow is essential to develop a vesicular mole.

There is trophoblastic proliferation with mitotic activity affecting both synctiotrophoblastic and cytrotrophoblastic layers. This causes excessive secretion of $\beta$-hCG, chorionic thyrotropin and progesterone. On the other hand, estrogen production is low due to absence of foetal supply of precursors. In complete mole, all or most of the villi are oedematous and there is diffuse trophoblastic hyperplasia. Cytogenetic studies of these moles show that more than $90 \%$ have $46, \mathrm{XX}$ diploid pattern all derived from the sperm. This phenomenon is called "androgenesis". They are presumed to result from fertilization of such an empty egg by two sperm (46 XX and XY). In partial moles, some of the villi are edematous and other villi show only minor changes. The trophoblastic proliferation is focal. In these moles, the karyotype is triploid (ed. 69, XXY) or even occasionally tetraploid. The moles result from fertilization of an egg with one or two sperm. The embryo is viable for weeks and thus fetal parts may be present when the resultant mole is aborted. Fels, Ernhart and Reossler demonstrated excessive levels of gonadotrophins in the urine of women with vesicular mole and noted that hCG in normal pregnancy and that secreted in trophoblastic disease is similar in chemical and immunological aspects

In present series, 39 women diagnosed as vesicular mole were studied between periods of October 2007 to May 2009. Out of them, 34 women were having complete mole and 5 were having partial mole. Sekharan PK found incidence of vesicular mole as 1 in 150 to 1 in 300 deliveries. $^{3}$ In the series by Dan Kaye the incidence was found to be 3.42 per 1000 deliveries. ${ }^{4}$ In present series, the incidence of vesicular mole was found to be 2.5 per 1000 deliveries. In a series of 942 cases studied by Sekharan PK risk of developing hydatidiform mole among teenagers was almost double and that for women over age 40 years was almost ten times compared to overall incidence. ${ }^{3}$ In the series done by Lawrence et al maximum number of women i.e. $56.94 \%$ were in the age group 20-30 years. ${ }^{5}$ Kaye D in his series found $41.4 \%$ women between the age group 20-30 years. ${ }^{4}$ Ong $\mathrm{HC}$ et al observed that hydatidiform mole occurred most commonly in the age group 25-29 years $36.3 \%, 38.2 \%$ women were less than 25 years of age while $25.5 \%$ were 30 years and above in age. ${ }^{6}$

\section{CONCLUSION}

In present series, study of 39 women diagnosed as vesicular mole was done during the period of October 2007 to May 2009. Incidence of vesicular mole was 2.5 per 1000 deliveries. Around 46.15\% women were in the age group 20-24 years followed by $33.33 \%$ in the age group of 25-29 year and $20.51 \%$ were in the teenage group. In molar pregnancy, $48.71 \%$ women belonged to urban area. In present series, $58.97 \%$ women were between gravidity $2-4,33.33 \%$ women were primigravida and around $7.69 \%$ women were gravidity 5 or more. Around $46.15 \%$ women were nulliparous followed by $30.76 \%$ were multiparous. There was no significant association of serum $\beta-\mathrm{hCG}>1,00,000 \mathrm{mlU} / \mathrm{ml}$ with raised TFTs.

\section{Funding: No funding sources}

Conflict of interest: None declared

Ethical approval: The study was approved by the Institutional Ethics Committee

\section{REFERENCES}

1. Chhabra S, Qureshi A. The Journal of Obstetrics and Gynaecology of India. 2007;57(2):124-7. 
2. Jonathan S. Berek. Berek and Novak Ganaecology. $14^{\text {th }}$ Edition; 2007:2151-2176.

3. Sekharan PK. The management of gestational trophoblastic neoplasia. FOGSI-ICOG consensus statement, India, 2006. Available from: http://www.icogonline.org/images/pdf/gcpguidelines /Gestational_T_Dis.pdf

4. Kaye DK. Gestational trophoblastic disease following complete hydatidiform mole in Mulago hospital, Kampala, Uganda. African Health Sci. 2002;2(2):47-51.
5. Bandy LC, Clarke-Pearson DL, Charles B. Hammond CB. Malignant potential of gestational trophoblastic disease at extreme ages of reproductive life. Obstet Gynecol. 1984 Sep;64(3):395-9.

6. Ong HC, Chong L. Clinical observations of hydatidiform moles in a Malaysian Hospital. Singapore Med J. 1978;19(1):33-6.

Cite this article as: Thakur HS. Clinical study of vesicular mole. Int J Reprod Contracept Obstet Gynecol 2017;6:1211-4. 